\title{
Correction to: The Xinjiang Case and Its Implications from a Business Ethics Perspective
}

\author{
Alexander Kriebitz ${ }^{1} \cdot$ Raphael Max $^{1}$
}

Published online: 13 August 2021

(C) The Author(s) 2021

\section{Correction to: Human Rights Review (2020) 21(3):243-265 https://doi.org/10.1007/s12142-020-00591-0}

The article "The Xinjiang Case and Its Implications from a Business Ethics Perspective", written by Alexander Kriebitz and Raphael Max, was originally published Online First without Open Access. After publication in volume 21, issue 3, page 243-265 the author decided to opt for Open Choice and to make the article an Open Access publication. Therefore, the copyright of the article has been changed to (C) The Author(s) 2021 and the article is forthwith distributed under the terms of the Creative Commons Attribution 4.0 International License, which permits use, sharing, adaptation, distribution and reproduction in any medium or format, as long as you give appropriate credit to the original author(s) and the source, provide a link to the Creative Commons licence, and indicate if changes were made. The images or other third party material in this article are included in the article's Creative Commons licence, unless indicated otherwise in a credit line to the material. If material is not included in the article's Creative Commons licence and your intended use is not permitted by statutory regulation or exceeds the permitted use, you will need to obtain permission directly from the copyright holder. To view a copy of this licence, visit http://creativeco mmons.org/licenses/by/4.0/. Open access funding enabled and organized by Projekt DEAL.

The original article has been corrected.

The original article can be found online at https://doi.org/10.1007/s12142-020-00591-0.

Alexander Kriebitz

a.kriebitz@tum.de

Raphael Max

r.max@tum.de

1 TUM School of Governance, Technical University of Munich, Arcisstr. 21, 80333 Muenchen, Germany 
Open Access This article is licensed under a Creative Commons Attribution 4.0 International License, which permits use, sharing, adaptation, distribution and reproduction in any medium or format, as long as you give appropriate credit to the original author(s) and the source, provide a link to the Creative Commons licence, and indicate if changes were made. The images or other third party material in this article are included in the article's Creative Commons licence, unless indicated otherwise in a credit line to the material. If material is not included in the article's Creative Commons licence and your intended use is not permitted by statutory regulation or exceeds the permitted use, you will need to obtain permission directly from the copyright holder. To view a copy of this licence, visit http://creativecommons.org/licen ses/by/4.0/.

Publisher's Note Springer Nature remains neutral with regard to jurisdictional claims in published maps and institutional affiliations. 